\title{
Distribution of calcium, phosphorus, sulfur, magnesium, potassium, and sodium in major fractions of donkey milk
}

\author{
F. Fantuz, ${ }^{1} \oplus$ S. Ferraro, ${ }^{2 *} \oplus$ L. Todini, ${ }^{1} \oplus$ L. Cimarelli, ${ }^{1} \oplus$ A. Fatica, ${ }^{3} \oplus$ F. Marcantoni, ${ }^{2}{ }^{\oplus}$ and E. Salimei ${ }^{3} \oplus$ \\ ${ }^{1}$ Scuola di Bioscienze e Medicina Veterinaria, Università degli Studi di Camerino, 62032 Camerino, Italy \\ ${ }^{2}$ Scuola di Scienze e Tecnologie, Università degli Studi di Camerino, 62032 Camerino, Italy \\ ${ }^{3}$ Dipartimento di Agricoltura, Ambiente, Alimenti, Università degli Studi del Molise, 86100 Campobasso, Italy
}

\section{ABSTRACT}

The aim of this study was to evaluate the concentrations of $\mathrm{Ca}, \mathrm{P}, \mathrm{S}, \mathrm{Mg}, \mathrm{K}$, and $\mathrm{Na}$, and their distribution in major fractions of donkey milk (i.e., fat, casein, whey proteins, and aqueous phase). Individual milk samples were collected by mechanical milking from 16 clinically healthy lactating donkeys. Milk yield per milking was recorded and milk gross composition, casein content, and $\mathrm{pH}$ were determined. Whole milk samples were centrifuged to separate fat and to obtain skim milk. Skim milk samples were ultracentrifuged to separate a sedimentable casein pellet and to obtain a supernatant whey (soluble) fraction, which was then ultrafiltered to obtain the aqueous phase of donkey milk. Whole milk and the processed samples were analyzed for the aforementioned elements by inductively coupled plasma-mass spectrometry. The concentration of elements associated with fat, casein, and whey proteins was then calculated. All the Na was present in the aqueous phase. The fat fraction in donkey milk carried very little or none of the investigated elements. The majority of $\mathrm{Ca}$ $(62.9 \%)$ and $\mathrm{P}(53.1 \%)$ was associated with casein, and the rest of these elements was mostly present in the aqueous phase. The majority of $\mathrm{Mg}$ was present in the aqueous phase, but a relevant part $(32.6 \%)$ was associated with the casein fraction. No K was associated with casein. On a molar basis, the ratio of colloidal $\mathrm{Ca}$ and $\mathrm{P}$ to casein (mmol/g of casein) was more than double the values reported in literature for cow milk. The correlation coefficient was negative between milk $\mathrm{pH}$ and $\mathrm{P}$ in the ultracentrifuged $(\mathrm{r}=-0.81)$ and ultrafiltered (aqueous) fraction $(\mathrm{r}=-0.66)$. Milk $\mathrm{pH}$ correlated positively with colloidal $\mathrm{Ca}(\mathrm{r}=0.59)$ and with the ratio of colloidal $\mathrm{Ca}$ to casein $(\mathrm{mmol} / \mathrm{g}$ of casein; $\mathrm{r}=$ 0.68). Colloidal $\mathrm{Ca}$ and $\mathrm{P}$ were positively correlated $(\mathrm{r}=0.64)$. These data suggest that the high ratio of

Received January 23, 2020.

Accepted May 18, 2020.

*Corresponding author: stefano.ferraro@unicam.it colloidal $\mathrm{Ca}$ and $\mathrm{P}$ to donkey casein micelles is due to a larger amount of colloidal calcium phosphate bound to casein micelles compared with literature data on cow milk. The percentage of elements associated with whey proteins was less than $5 \%$ for $\mathrm{Ca}, \mathrm{P}$, and $\mathrm{K}$, but $\mathrm{Mg}$ reached approximately $9 \%$ of total $\mathrm{Mg}$. The majority of S $(63.6 \%)$ was associated with whey proteins, and only one-fourth of this element was associated with casein, indicating a higher content of sulfur-containing amino acids in donkey whey proteins than in casein.

Key words: donkey milk, casein, colloidal minerals, soluble minerals

\section{INTRODUCTION}

Donkey (Equus asinus, class Mammalia, order Perissodactyla, family Equidae) has been known as a dairy species since ancient times and was successfully used in the late nineteenth century for feeding orphan infants in Paris (Salimei, 2011). In recent years, scientific interest in donkey as a dairy species has grown mostly because clinical studies demonstrated that donkey milk can be used for children suffering IgE- and non-IgE-mediated cow milk allergy, when adequately supplemented (Salimei and Fantuz, 2013; Sarti et al., 2019). Nowadays, donkey milk is a niche product and is mainly marketed for human consumption as raw, pasteurized, or powdered (either spray- or freeze-dried), and as fermented derivatives (Turchi et al., 2017; Miraglia et al., 2020). Knowledge about macronutrients has greatly increased in the last $15 \mathrm{yr}$, but a limited number of studies are available on the macromineral concentration in donkey milk. Differences exist among milk from cow, human, and donkey. The content of macrominerals in cow milk, and in milk from other ruminant dairy species, is remarkably higher than that of human milk. On the contrary, donkey milk shows similarities with human milk for $\mathrm{Na}$ and $\mathrm{K}$, being intermediate between human and cow milk for $\mathrm{Ca}, \mathrm{P}$, and $\mathrm{Mg}$ concentration, as reviewed by Fantuz et al. (2016). Macrominerals are present in milk as free ions or salts in solution, or complexed with proteins, mainly with caseins as colloidal 
species (Gaucheron, 2011). Caseins $\left(\alpha_{\mathrm{S}^{-}} \mathrm{CN}, \alpha_{\mathrm{S} 2}-\mathrm{CN}\right.$, $\beta-\mathrm{CN}$, and $\kappa-\mathrm{CN}$ ) have been extensively studied in cow milk, where they represent about $80 \%$ of total protein and exist as large aggregates of colloidal size known as casein micelles (Dalgleish and Corredig, 2012). Donkey milk contains approximately one-half protein compared with cow milk, and caseins represent less than $50 \%$ of total protein (Fantuz et al., 2016). Among the main biological functions of casein micelles, in addition to that of supplying amino acids (and peptides with biological functions) to the newborn, are the safe secretion (in liquid form) of high concentrations of $\mathrm{Ca}$ and $\mathrm{P}$ preventing the mammary gland from becoming calcified, the safe secretion of high concentrations of potentially fibrillogenic casein proteins through the mammary gland, and the retention of micelles in the stomach of the neonate allowing digestion and absorption of nutrients. Such biological functions and the structure of the casein micelles are closely related (Holt et al., 2013). Milk is supersaturated of low soluble calcium phosphate whose concentration is higher than can be kept in solution at normal $\mathrm{pH}$ of cow milk (6.5-6.7), and $\mathrm{Ca}$ and $\mathrm{P}$ (and $\mathrm{Mg})$ are distributed between the soluble and the colloidal phase (Fox et al., 2015). Aggregation of individual caseins into casein micelles occurs through a combination of hydrophobic interactions between hydrophobic regions of the caseins, and electrostatic interaction mediated by nanoclusters of calcium phosphate (known as colloidal calcium phosphate; CCP) sequestered in an amorphous form between phosphorylation sites located at hydrophilic regions of the caseins (Horne, 1998). The active function of calcium phosphate in defining the micellar structure is well known (Dalgleish, 2011; Dalgleish and Corredig, 2012). Colloidal Ca is associated with casein both directly bound to organic phosphate groups of caseins and as a component of CCP. Colloidal $\mathrm{P}$ is present both bound to phosphorylation sites of serine residues of caseins (organic $\mathrm{P}$ ) and as a component of CCP (inorganic phosphate; Gaucheron, 2011).

The distribution of minerals, particularly $\mathrm{Ca}$ and $\mathrm{P}$, among different milk fractions has crucial effects for the technological and nutritional properties of milk (Bijl et al., 2013). Mineral distribution plays a role in processes involving casein micelle coagulation, such as acid and rennet coagulation in the manufacture of yogurt and cheese. Donkey milk is susceptible to acid-induced and rennet-induced coagulation at $\mathrm{pH} 6.6$, but producing a weak gel compared with cow milk (Uniacke-Lowe, 2011). Moreover, it may provide sufficient firm curd only at extreme technological conditions (in terms of $\mathrm{pH}$, amount of calcium chloride added, amount of rennet added, and temperature of coagulation) for cheesemaking (Faccia et al., 2018). Additionally, because of the high content of lysozyme, donkey milk can be suc- cessfully used as an alternative to the addition of hen's egg white lysozyme in preventing cheese blowing during ripening of Italian hard cheeses (Niro et al., 2017). On this regard, it is reported that the antibacterial activity of donkey milk, mainly due the high concentration of lysozyme, is affected by factors such as the addition of divalent cations or Ca chelatants, known for modifying the distribution of minerals in milk (Šarić et al., 2014). In cow milk, knowledge of physicochemical factors affecting mineral distribution (i.e., temperature, $\mathrm{pH}$, addition of di- and trivalent cations, addition $\mathrm{Ca}$ chelatants, among others), allowed optimization of methods for milk processing throughout the dairy chain (Gaucheron, 2011; Dalgleish and Corredig, 2012; Bijl et al., 2013).

Coagulation of casein in the stomach is also important from a nutritional point of view because the characteristics of the coagulum affect digestibility (Uniacke-Lowe, 2011). Upon the action of pepsin or of acidification in vitro, human milk produces fine clots, apparently shortening the gastric emptying time compared with the coarser clot of cow milk (Nakai and Li Chan, 1987). Furthermore, it is believed that the efficiency of absorption of some elements from human milk is higher than cow milk-based infant formula and this could be partially related to the different distribution of elements in milk fractions (Lonnerdal, 1997).

Despite the importance of mineral distribution on technological and nutritional properties of milk, little information is available in literature for donkey milk, mainly limited to $\mathrm{Ca}$ and inorganic $\mathrm{P}$, and data were obtained by different methods for milk fractionation (O'Connor and Fox, 1977; Li et al., 2010; Malacarne et al., 2017).

The aim of this study was to evaluate the concentration of $\mathrm{Ca}, \mathrm{P}, \mathrm{S}, \mathrm{Mg}, \mathrm{K}$, and $\mathrm{Na}$, and their distribution in major fractions of donkey milk (i.e. fat, casein, whey proteins, and aqueous phase).

\section{MATERIALS AND METHODS}

\section{Animals, Diet, and Sampling}

This study was carried out at a private dairy donkey farm, located in a mountainous area of L'Aquila province, Italy (alt $398 \mathrm{~m}$ above sea level; $42^{\circ} 17^{\prime} 11.34^{\prime \prime}$ $\left.\mathrm{N} ; 13^{\circ} 45^{\prime} 43.57^{\prime \prime} \mathrm{E}\right)$. The research protocol was in accordance with the European Commission guidelines (2010/63/EU; European Union, 2010) concerning the protection of animals used for experimental and other scientific purposes.

Individual milk samples were provided by 16 clinically healthy lactating donkeys (6 Amiata and 10 Ragusana breed), averaging ( $\pm \mathrm{SD}) 7.38( \pm 1.54)$ yr old, 
$3.81( \pm 1.38)$ parities, and $126( \pm 56)$ d from foaling. The experimental subjects were group fed $1.5 \mathrm{~kg} / \mathrm{d}$ of a concentrate mixture made by equal parts of corn and oat, and had continuous access to alfalfa hay and fresh water. Donkeys were housed with the foals that were separated from the dam $3 \mathrm{~h}$ before milking and the milk samples were collected by machine milking (Salimei et al., 2004) during the afternoon milking $(1600 \mathrm{~h})$ and refrigerated $\left(8^{\circ} \mathrm{C}\right)$ until fractionation. Individual milk yield was recorded. A 3\% nitric acid solution (Suprapur quality, Merck, Darmstadt, Germany) were used for previous washing of all glassware and polyethylene tubes used for collection, storage, and analysis of samples.

\section{Fractionation of Milk}

Milk samples were kept at room temperature $\left(20^{\circ} \mathrm{C}\right)$ for $3 \mathrm{~h}$ before the first step of the separation process, occurred within $15 \mathrm{~h}$ from collection. Whole milk samples $(\mathrm{n}=16)$ were centrifuged at $1,000 \times g, 20$ min at room temperature to separate fat and to obtain skim milk as described by Uniacke-Lowe et al. (2013). Skim milk samples were ultracentrifuged (rotor $50 \mathrm{Ti}$, Beckman L7-55 centrifuge, Beckman Coulter, Brea, CA) at $100,000 \times g$ for $60 \mathrm{~min}$ at $4^{\circ} \mathrm{C}$ to separate a sedimentable casein pellet and to obtain a supernatant whey (soluble) fraction (Anastácio et al., 2004), which was then ultrafiltered (Amicon, Ultra-4, cut-off $3 \mathrm{kDa}$; Sigma-Aldrich, Milano, Italy) at 7,500 $\times g$ for $60 \mathrm{~min}$ at room temperature to obtain the aqueous phase of donkey milk. Aliquots of whole milk, skimmed, ultracentrifuged, and ultrafiltered milk fractions were frozen at $-21^{\circ} \mathrm{C}$ until analysis.

\section{Milk Fractions and Feedstuff Analysis}

Total nitrogen and noncasein nitrogen in individual milk samples were analyzed by Kjeldahl method on whole milk and acid whey at $\mathrm{pH} 4.6$, as previously indicated (Salimei et al., 2004). Total nitrogen and casein nitrogen, obtained subtracting noncasein nitrogen to total nitrogen, were then converted to percentage of $\mathrm{CP}$ and casein using the conversion factor of 6.38. Milk fat and lactose were determined by infrared (Milkoscan 605, Foss Italia, Padova, Italy). Milk $\mathrm{pH}$ was measured immediately before defatting by a potentiometer (Knick Portamess, Germany). The SCC (Fossomatic 360, Foss, Hillerød, Denmark) and the total bacteria count (Bactoscan 8000, Foss) were determined in whole milk samples to check for the health status of the mammary gland and milk hygiene. Feedstuffs were analyzed for $\mathrm{CP}$, ether extract, NDF, $\mathrm{ADF}$, and ash content (AOAC, 2000).
Ultrapure water obtained from a Millipore Milli-Q system (resistivity $18.2 \mathrm{M} \Omega \mathrm{cm}$ ) was used to prepare all solutions for analysis of elements. Thawed samples of whole milk and fractions were sonicated for $10 \mathrm{~min}$ in an ultrasound water bath (Ultrasonik 300 QT Heat, NEY, Barkmeyer Division, Yucaipa, CA) before mineralization (Cava-Montesinos et al., 2005). To mineralize whole milk samples $(\mathrm{n}=16)$ and the corresponding skimmed, ultracentrifuged, and ultrafiltered fractions, $1.5 \mathrm{~mL}$ of sample placed in a Teflon digestion vessel was added with $1 \mathrm{~mL}$ of $\mathrm{HNO}_{3}(65 \%$, Suprapur quality, Merck), $4 \mathrm{~mL}$ of $\mathrm{H}_{2} \mathrm{O}_{2}, 0.5 \mathrm{~mL}$ of Ultrapure water, and $50 \mu \mathrm{L}$ of a solution $(2 \mathrm{mg} / \mathrm{L})$ of $\mathrm{Be}, \mathrm{Ru}$, and $\mathrm{Au}$ as recovery standard. A microwave closed vessel system (Berghof Speedwave 4, Berghof, Eningen, Germany) was used for mineralization. Mineralized solutions were transferred to a $10-\mathrm{mL}$ volumetric flask and diluted with ultrapure water, then diluted again 1:10 with ultrapure water. The same process was used to mineralize samples $(0.15 \mathrm{~g})$ of feedstuff. The concentrations of $\mathrm{Ca}, \mathrm{P}, \mathrm{S}, \mathrm{Mg}, \mathrm{K}$, and $\mathrm{Na}$ in the mineralized solution were measured by inductively coupled plasma-MS (7500cx series, Agilent Technologies, Santa Clara, CA) with the following operating conditions: power 1,550 $\mathrm{W}$, carrier gas $1.03 \mathrm{~L} / \mathrm{min}$, make-up gas $0.00 \mathrm{~L} / \mathrm{min}$, sample depth $8 \mathrm{~mm}$, nebulizer pump $0.1 \mathrm{rps}$, and spray chamber temperature $2^{\circ} \mathrm{C}$. The $7500 \mathrm{cx}$ series instrumentation can be operated in He mode to overcome most of the polyatomic interference by the collision cell. A typical performance test in He mode was as follows: He flux $4.2 \mathrm{~mL} / \mathrm{min}$, solution containing $10 \mathrm{ppb}$ of ${ }^{9} \mathrm{Be}$ $(10,500 \mathrm{cps}),{ }^{45} \mathrm{Sc}(37,500 \mathrm{cps}),{ }^{56} \mathrm{ArO}(224 \mathrm{cps}),{ }^{115} \mathrm{In}$ (40,000 cps), ${ }^{140} \mathrm{Ce}(47,000 \mathrm{cps})$, and ${ }^{209} \mathrm{Bi}(18,000 \mathrm{cps})$. The same solution without ${ }^{9} \mathrm{Be}$ was used as internal standard for inductively coupled plasma-MS measurements. Calibration curves for the investigated elements were obtained using aqueous (1\% nitric acid) standard solutions prepared with appropriate dilution of stock standards (Fluka Analytical, Sigma-Aldrich). The accuracy of the analytical procedure was checked within each batch analysis, by analysis of blanks and of certified reference material, skim milk powder ERM-BD151 (European Reference Material, Geel, Belgium). For the purpose of the present study, analytical results were in good agreement with certified values in reference material (certified, g/kg: Ca 13.9, P 11.0, Mg 1.26, K 17.0, and $\mathrm{Na} 4.19$; observed, $\mathrm{g} / \mathrm{kg}$, mean $\pm \mathrm{SD}$ : Ca $13.75 \pm$ $0.68, \mathrm{P} 9.41 \pm 0.43, \mathrm{~S} 3.46 \pm 0.08, \mathrm{Mg} 1.265 \pm 0.05, \mathrm{~K}$ $17.20 \pm 0.58$, and $\mathrm{Na} 4.21 \pm 0.15)$.

The concentration of elements associated with fat was calculated as the difference between their concentration in corresponding individual whole and skim milk. The concentration of elements associated with casein (colloidal form) and whey proteins was calculated as the 
Table 1. Dry matter content (g/100 g), nutrient (g/100 g of DM), and mineral $(\mathrm{g} / \mathrm{kg}$ of $\mathrm{DM})$ composition of feedstuffs

\begin{tabular}{lccc}
\hline Item & Alfalfa hay & Maize & Oat \\
\hline $\mathrm{DM}$ & 85.8 & 86.7 & 86.3 \\
$\mathrm{CP}$ & 16.6 & 9.2 & 10.3 \\
Ether extract & 2.2 & 4.1 & 6.6 \\
$\mathrm{NDF}$ & 46.3 & 9.1 & 30.8 \\
$\mathrm{ADF}$ & 35.5 & 3.3 & 16.8 \\
$\mathrm{Ash}$ & 9.9 & 2.0 & 2.9 \\
$\mathrm{Ca}$ & 15.7 & 0.70 & 1.27 \\
$\mathrm{P}$ & 1.28 & 1.90 & 2.21 \\
$\mathrm{~S}$ & 2.91 & 1.06 & 1.25 \\
$\mathrm{Mg}$ & 2.62 & 1.06 & 1.27 \\
$\mathrm{~K}$ & 29.0 & 3.82 & 4.66 \\
$\mathrm{Na}$ & 0.40 & 0.03 & 0.04 \\
\hline
\end{tabular}

difference between their concentration in whole milk and in ultracentrifuged samples, and between their concentration in ultracentrifuged and ultrafiltered samples (aqueous phase), respectively. The percentage distribution of each elements in casein, whey proteins, fat, and aqueous phase was calculated and expressed referring to their concentration in whole milk.

\section{SDS-PAGE}

Proteins present in skim milk and in ultracentrifuged and ultrafiltered fractions were detected by SDSPAGE. Seven $\mu \mathrm{L}$ of each milk fraction were mixed with $4 \mu \mathrm{L}$ of concentrated sample buffer $(0.125 \mathrm{M}$ Tris- $\mathrm{HCl}$ pH 6.8; $2 \%$ SDS, $20 \%$ glycerol, $1 \%$ 2-mercaptoethanol, and $0.3 \%$ bromophenol blue as tracking dye), heated at $95^{\circ} \mathrm{C}$ for $5^{\prime}$, and loaded on a $15 \%$ acrylamide/ $N, N$ methylenebisacrylamide gel. Electrophoresis was performed at $160 \mathrm{~V}$ using a Mini-PROTEAN 3 apparatus (Bio-Rad, Hercules, CA). Bovine serum albumin $(66.5 \mathrm{kDa})$, carbonic anhydrase $(29 \mathrm{kDa})$, and hen egg white lysozyme $(14.3 \mathrm{kDa})$ were used as molecular weight markers (Sigma-Aldrich). Proteins were stained by a staining solution $(1 \mathrm{~g} / \mathrm{L}$ Coomassie Brilliant Blue R-250 in 50\% methanol and 10\% acetic acid). Polyacrylamide gel was destained with a solution containing $10 \%$ methanol and $10 \%$ acetic acid.

\section{Statistical Analysis}

Data on element concentration in individual whole milk samples and in the corresponding skimmed, ultracentrifuged, and ultrafiltered fractions were used to determine, by ANOVA for repeated measures (SPSS Inc., Chicago, IL), the effect of breed (between-subject factor) and the effect of milk fractionation (fat, casein, and whey proteins removal; within-subject factor). The variable "days from foaling" was used as covariate. In case of significant effects $(P<0.05)$, differences between means were analyzed by least significant difference. Simple linear correlations were also considered. Values of $P<0.05$ were considered significant.

\section{RESULTS AND DISCUSSION}

The gross chemical composition and the concentration of the investigated elements in feedstuffs (Table 1) were substantially consistent with the available literature data (McDowell and Valle, 2000; Suttle, 2010). Results on the average milk yield per milking, gross milk composition, $\mathrm{pH}, \mathrm{SCC}$, and total bacteria count are reported in Table 2, and were in the range previously reported for donkey milk (Salimei et al., 2004; Guo et al., 2007; Massouras et al., 2017). The low levels of SCC and total bacteria count in milk samples indicate a good milk hygiene and health of the mammary gland (Table 2).

The concentration of $\mathrm{Ca}, \mathrm{P}, \mathrm{Mg}, \mathrm{S}, \mathrm{K}$, and $\mathrm{Na}$ in whole donkey milk and in the fractionated samples is reported in Table 3. We observed that the concentration of $\mathrm{Ca}, \mathrm{K}, \mathrm{Na}$, and $\mathrm{Mg}$ in whole donkey milk was in close agreement with our previous findings (Fantuz et al., 2012) but milk $\mathrm{P}$ concentration was lower in the current study, although in agreement with results by Salimei et al. (2004). Data on Ca were also similar to those from Bilandzic et al. (2014) and Massouras et al. (2017). Other studies reported a lower Ca concentration to various extents for donkey milk (Salimei et al., 2004; Fantuz et al., 2009; Martini et al., 2018; Malacarne et al., 2019). Lower K (Salimei et al., 2004; Massouras

Table 2. Milk yield per milking, $\mathrm{pH}$, and gross chemical composition

\begin{tabular}{lccc}
\hline Item & Mean $\pm \mathrm{SD}$ & Minimum & Maximum \\
\hline Milk yield per milking, $\mathrm{mL}$ & $765.6 \pm 167$ & 400 & 1,100 \\
Protein, \% & $1.33 \pm 0.11$ & 1.18 & 1.52 \\
Casein, \% & $0.62 \pm 0.05$ & 0.53 & 0.76 \\
Fat, \% & $0.41 \pm 0.11$ & 0.35 & 0.80 \\
Lactose, \% & $6.59 \pm 0.1$ & 6.43 & 6.79 \\
pH & $7.45 \pm 0.11$ & 7.29 & 7.65 \\
Total bacteria count, cfu/mL & $4,400 \pm 1,882$ & 2,000 & 8,000 \\
SCC, no./mL & $<10,000$ & & \\
\hline
\end{tabular}


Table 3. Concentration of macroelements expressed as $\mathrm{mg} / \mathrm{L}$ (and mmol/L in parentheses) in whole donkey milk and in skimmed (removal of fat), ultracentrifuged (removal of caseins), and ultrafiltered (removal of whey proteins, aqueous phase) milk samples

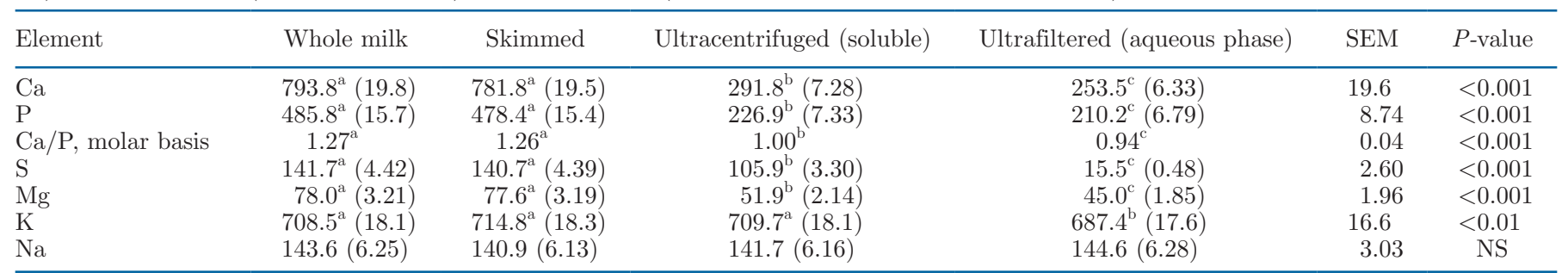

${ }^{\mathrm{a}-\mathrm{c}}$ Means within a row with different superscripts differ $(P<0.05)$.

et al., 2017) and higher $\mathrm{Na}$ concentrations were also observed (Salimei et al., 2004; Massouras et al., 2017; Malacarne et al., 2019). Differences can be related to the effect of stage of lactation, which has been observed in some studies (Fantuz et al., 2012; Massouras et al., 2017; Malacarne et al., 2019). Other factors such as the breed, health of the mammary gland, and diet, in some cases, are reported to affect the content of macroelements in cow milk (Fox et al., 2015), but specific data are not available for donkey milk.

No data are available for $\mathrm{S}$ in donkey milk, but our results (Table 3) are consistent with those found in human milk (142 mg/L) and lower than cow milk (299 $\mathrm{mg} / \mathrm{kg}$; Darragh and Lonnerdal, 2011; Stergiadis et al., 2019), reflecting the lower content of both protein- and S-containing amino acids (g/100 g of milk) in donkey than cow milk (Salimei et al., 2004; Guo et al., 2007; Massouras et al., 2017).

The effect of breed on the investigated minerals in different milk fractions was not significant (results not shown), nor was the effect of the covariate "days from foaling."

Sodium concentration did not differ among whole, skimmed, ultracentrifuged, and ultrafiltered samples, with all the $\mathrm{Na}$ being present in the aqueous phase (Table 3). Although the effect of complete milk fractionation was significant for $\mathrm{Ca}(P<0.001), \mathrm{P}(P<$ $0.001), \mathrm{S}(P<0.001), \mathrm{Mg}(P<0.001)$, and $\mathrm{K}(P<$ 0.01; Table 3$)$, the concentration of all elements was not affected by fat removal; thus, the small fat fraction in donkey milk (Table 2) carried no or very little amount of the investigated elements. The few studies published on the distribution of elements in donkey or mare milk did not consider the fat fraction. Our results are consistent with those reported on cow milk, in which no $\mathrm{Mg}$ and $1 \%$ of total $\mathrm{Ca}$ is associated with fat, whereas in human milk, from 10 to $16 \%$ of $\mathrm{Ca}$, and $2 \%$ of $\mathrm{Mg}$ were reported to be associated with the fat fraction (Lonnerdal, 1997).

Proteins present in skimmed, ultracentrifuged, and ultrafiltered samples were visualized by SDS-PAGE as shown in Figure 1. No visible bands attributable to caseins were present in the ultracentrifuged samples and no visible proteins were present in ultrafiltered (cut-off $3 \mathrm{kDa}$ ) samples (Figure 1), indicating the efficacy of the methods in removing casein and major whey proteins. Calcium, P, S, and Mg concentrations were significantly reduced by casein and whey protein removal, whereas $\mathrm{K}$ concentration was not affected by casein removal and was significantly but only slightly reduced by whey protein removal (Table 3). The calculated percentage of elements associated with casein, whey proteins, and aqueous phase is summarized in Table 4 . The majority of $\mathrm{Ca}$ and $\mathrm{P}$ was associated with casein with the rest of these elements being mostly present in the aqueous phase. The majority of $\mathrm{Mg}$ was present in the aqueous phase but a relevant part was associated with the casein fraction. Most of $\mathrm{S}$ was associated with whey

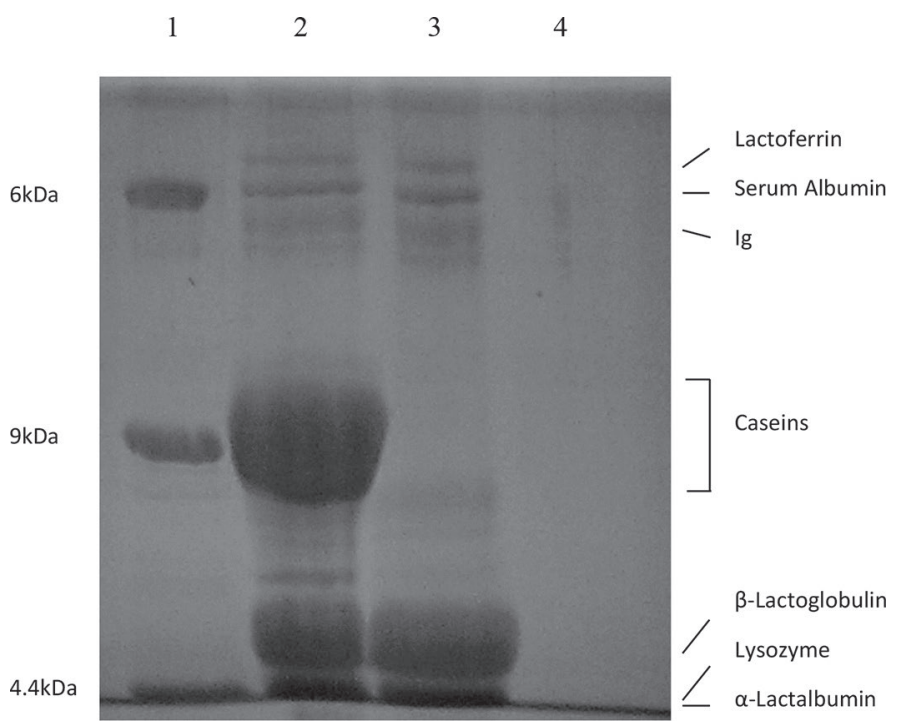

Figure 1. Electrophoretic separation of major proteins in different fractions of donkey milk on 15\% SDS-PAGE. Lane 1: Molecular weight markers (BSA $66 \mathrm{kDa}$; carbonic anhydrase $29 \mathrm{kDa}$; lysozyme 14.4 kDa). Lane 2: skim milk. Lane 3: ultracentrifuged whey (soluble) fraction. Lane 4: ultrafiltered fraction (cut-off $3 \mathrm{kDa}$, aqueous phase). 
Table 4. Distribution of the investigated elements in donkey milk, calculated as a percentage (mean \pm SD) of that in whole milk and as a concentration $(\mathrm{mmol} / \mathrm{L}$; mean $\pm \mathrm{SD})$ of elements associated with major fractions of donkey milk

\begin{tabular}{|c|c|c|c|c|c|c|c|}
\hline \multirow[b]{2}{*}{ Element } & \multicolumn{3}{|c|}{ Element associated with caseins (colloidal) } & \multicolumn{2}{|c|}{$\begin{array}{c}\text { Element associated with whey } \\
\text { proteins }\end{array}$} & \multicolumn{2}{|c|}{ Element in aqueous phase } \\
\hline & $\%$ of total & $\mathrm{mmol} / \mathrm{L}$ & $\mathrm{mmol} / \mathrm{g}$ of casein & $\%$ of total & $\mathrm{mmol} / \mathrm{L}$ & $\%$ of total & $\mathrm{mmol} / \mathrm{L}$ \\
\hline $\mathrm{Ca}$ & $62.9 \pm 2.9$ & $12.3 \pm 3.0$ & $2.04 \pm 0.32$ & $4.78 \pm 2.5$ & $1.01 \pm 0.45$ & $32.3 \pm 3.4$ & $6.40 \pm 0.96$ \\
\hline $\mathrm{P}$ & $53.1 \pm 3.9$ & $8.17 \pm 1.44$ & $1.36 \pm 0.21$ & $3.41 \pm 2.3$ & $0.60 \pm 0.31$ & $43.4 \pm 3.2$ & $6.76 \pm 0.59$ \\
\hline S & $25.3 \pm 3.0$ & $1.12 \pm 0.20$ & $0.18 \pm 0.03$ & $63.6 \pm 3.2$ & $2.81 \pm 0.34$ & $11.0 \pm 2.1$ & $0.48 \pm 0.09$ \\
\hline $\mathrm{Mg}$ & $32.6 \pm 8.8$ & $1.07 \pm 0.16$ & $0.17 \pm 0.05$ & $8.83 \pm 4.1$ & $0.29 \pm 0.14$ & $58.5 \pm 5.9$ & $1.87 \pm 0.22$ \\
\hline
\end{tabular}

proteins with only one-fourth of this element associated with casein and a smaller percentage present in the aqueous phase.

Published data about colloidal elements reported values of approximately $65 \%$ of total $\mathrm{Ca}$, obtained for donkey milk by renneting (O'Connor and Fox, 1977), and $69.3 \%$ of $\mathrm{Ca}, 63.81 \%$ of $\mathrm{P}$, and $31.2 \%$ of $\mathrm{Mg}$ obtained by ultrafiltration (cut-off $30 \mathrm{kDa}$; Malacarne et al., 2017). A higher percentage of colloidal Ca (approximately $88 \%$ ), evaluated by ultracentrifugation, was also observed ( $\mathrm{Li}$ et al., 2010). Colloidal Ca in mare milk was observed to be approximately $61 \%$ (ultrafiltration; Holt and Jennes, 1984) or $67 \%$ (ultracentrifugation; Uniacke-Lowe, 2011) of total Ca. In cow milk, colloidal $\mathrm{Ca}, \mathrm{P}$, and $\mathrm{Mg}$ were reported to account for $66.5,57$, and $33 \%$ of total concentration, respectively (Fox et al., 2015), compared with only $6 \%$ for colloidal $\mathrm{Ca}$ and $\mathrm{Mg}$ in human milk (Lonnerdal, 1997). In addition, $8 \%$ of $\mathrm{Na}(40 \mathrm{mg} / \mathrm{L})$ and $\mathrm{K}(110 \mathrm{mg} / \mathrm{L})$ were also reported to be associated with the casein fraction in cow milk (Fox et al., 2015).

Yet, donkey milk contains approximately 33\% less $\mathrm{Ca}$ and $43 \%$ less P, but it also contains $76 \%$ less casein than cow milk (Fantuz et al., 2016). On a molar basis, the ratio of colloidal $\mathrm{Ca}$ and $\mathrm{P}$ to casein $(\mathrm{mmol} / \mathrm{g}$ of casein; Table 4) was more than double than that reported for cow milk (O'Connor and Fox, 1977; Malacarne et al., 2015). Compared with literature data obtained by renneting or ultrafiltration for donkey milk, the ratio of colloidal element to casein was similar for $\mathrm{Mg}$ and slightly higher or lower for $\mathrm{Ca}$ and $\mathrm{P}$, respectively (O'Connor and Fox, 1977; Malacarne et al., 2017). However, it should be noted that, compared with our results, the studies by O'Connor and Fox (1977) and Malacarne et al. (2017) reported higher or lower levels of casein and $\mathrm{Ca}$, respectively. The molar $\mathrm{Ca} / \mathrm{P}$ ratio associated with the casein fraction (Table 4) was higher than that previously reported for donkey milk (1.07; Malacarne et al., 2017). We measured the concentration of colloidal total $\mathrm{P}$, and assuming that colloidal inorganic $\mathrm{P}$ in donkey milk represents approximately $76 \%$ of total P (Malacarne et al., 2017), we calculate the average concentration of colloidal inorganic $\mathrm{P}$ in our samples at $6.21 \mathrm{mmol} / \mathrm{L}$. This gives an estimate of colloidal $\mathrm{Ca}$ /inorganic $\mathrm{P}$ ratio at 1.97 , which is comparable to that reported by O'Connor and Fox (1977) for donkey milk (1.87), and close to that (1.7) reported for CCP in cow milk (Fox et al., 2015). Our results, in agreement with those by Malacarne et al. (2017) obtained by ultrafiltration, suggest that the high ratio of colloidal $\mathrm{Ca}$ and $\mathrm{P}$ to donkey casein micelles is due to a larger amount of $\mathrm{CCP}$ bound to casein micelles compared with cow milk. This could partially explain the scarce influence of low temperature on solubility of donkey $\beta$-CN. Changes in mineral distribution, among other factors, affect the distribution of individual caseins. The equilibrium of elements distribution between the colloidal and the soluble phase of milk is affected, as that of micellar stability, by some physical factors including changes of $\mathrm{pH}$ and temperature (Gaucheron, 2011). In cow milk, the solubility of CCP milk increases with cooling $\left(<5^{\circ} \mathrm{C}\right)$, resulting in considerable dissociation of $\beta$-CN from the casein micelle into the soluble whey fraction (Dalgleish, 2011; Gaucheron, 2011). In our study ultracentrifugation was carried out at $4^{\circ} \mathrm{C}$ for $1 \mathrm{~h}$, but no visible caseins were present in the ultracentrifuged milk (Figure 1). On the one hand, this can be because the duration of cooling was too short to determine substantial solubilization of casein resulting in visible bands in the ultracentrifuged fraction. On the other hand, it is reported that donkey (O'Connor and Fox, 1973; Salimei et al., 2004; Li et al., 2010) and mare (Ochirkhuyag et al., 2000; Uniacke-Lowe, 2011) $\beta$-CN has low level of temperature-dependent dissociation from micelles. Nonetheless, it is known that $\beta-\mathrm{CN}$ in cow milk micelles exists as 3 conditions: cross-linked by CCP; not cross-linked by CCP and released on cooling (hydrophobically bound); not cross-linked by CCP and not released on cooling (Aoki et al., 1990). It was reported that enriching a cow casein dispersion prepa- 
ration with $\mathrm{CCP}$, to a large extent, decreases (from 31.8 to $2.1 \%$ ) the amount of $\beta-\mathrm{CN}$ released from casein micelles on cooling, accompanied by an increase in the proportion of $\beta-\mathrm{CN}$ cross-linked by $\mathrm{CCP}$ as well as the proportion of $\beta$-CN not cross-linked to $\mathrm{CCP}$ and not released on cooling (Aoki et al., 1990).

Current results for colloidal $\mathrm{Ca}$ and $\mathrm{P}$ in donkey milk are likely related to the higher $\mathrm{pH}$ of donkey than cow milk and, possibly, to the different ratio among individual caseins (Dalgleish and Corredig, 2012; Cunsolo et al., 2017). In cow milk a decrease of $\mathrm{pH}$ solubilizes CCP from casein micelle, whereas an increase of milk $\mathrm{pH}$ determines a shift from soluble $\mathrm{Ca}$ and inorganic $\mathrm{P}$ to the colloidal form as CCP (McGann and Pyne, 1960; Vaia et al., 2006; Ahmad et al., 2009; Ozcan et al., 2011). In our study the correlation coefficient was negative and significant between milk $\mathrm{pH}$ and $\mathrm{P}$ in the ultracentrifuged $(\mathrm{r}=-0.81)$ and ultrafiltered (aqueous) fraction $(\mathrm{r}=-0.66)$, but in the same fractions the $\mathrm{pH}$ did not significantly correlate with Ca. Milk pH correlated positively with colloidal $\mathrm{Ca}(\mathrm{r}=0.59)$ and with the ratio of colloidal Ca to casein ( $\mathrm{mmol} / \mathrm{g}$ casein; $\mathrm{r}=0.68$ ) but not with the homologous variables for $\mathrm{P}$. Nonetheless, colloidal $\mathrm{Ca}$ and $\mathrm{P}$ were significantly and positively correlated $(\mathrm{r}=0.64)$. These results further support the hypothesis that the high ratio of colloidal $\mathrm{Ca}$ and $\mathrm{P}$ to donkey casein micelles is due to a larger amount of CCP bound to casein micelles than to cow milk. These data may be relevant for the nutrient characteristics of donkey milk as well as for its technological properties. Because donkey milk is often marketed as a fermented derivative (Turchi et al., 2017; Miraglia et al., 2020), it has to be considered that, in cow milk, increasing the amount of $\mathrm{Ca}$ bound to casein as CCP by alkalization affects the texture of yogurt (Ozcan et al., 2011).

Another factor that can affect the ratio of colloidal element to casein is the number of phosphate group carried by caseins (organic $\mathrm{P}$ ), which is related to the number of serine residues (Gaucheron, 2011; Dalgleish and Corredig, 2012). The larger amount of CCP bound to casein in donkey milk could also be related to a higher degree of phosphorylation of donkey casein micelles than cow, but this hypothesis needs to be verified by specific studies. Indeed, donkey $\beta-\mathrm{CN}$, the main individual casein in donkey milk, is phosphorylated with $5 \mathrm{P}$ to $7 \mathrm{P} / \mathrm{mol}$, whereas cow $\beta$-CN is phosphorylated with $5 \mathrm{P} / \mathrm{mol}$, occasionally 4 . However, $\alpha_{S_{1}} \mathrm{CN}$, the main individual casein in cow milk, is phosphorylated with $8 \mathrm{P} / \mathrm{mol}$, compared with donkey $\alpha_{\mathrm{S}_{1}-\mathrm{CN}}$, which is phosphorylated with $5 \mathrm{P}$ and $6 \mathrm{P} / \mathrm{mol}$ (Fox et al., 2015; Cunsolo et al., 2017).
In the current study a small, although significant, amount of $\mathrm{Ca}, \mathrm{P}, \mathrm{Mg}$, and $\mathrm{K}$ was associated with whey proteins (Tables 3 and 4). In donkey milk, $\alpha$-LA and lysozyme bind $\mathrm{Ca}$, and some minor forms of $\alpha$-LA in cow milk may contain $\mathrm{P}$, but no information is available about association of whey proteins with $\mathrm{Mg}$ and K (Godovac-Zimmermann et al., 1988; Giufrida et al., 1992; Fox et al., 2015). The significant correlation between $\mathrm{S}$ and protein $(\mathrm{r}=0.87)$ and $\mathrm{S}$ and casein $(\mathrm{r}$ $=0.57)$ and the largest concentration of $\mathrm{S}$ associated with whey proteins observed in our study (Table 4) indicate a higher content of S-containing amino acids in donkey whey proteins than casein, as occur for other species. In cow milk, whey proteins, and mainly $\beta$-LG and $\alpha-\mathrm{LA}$, are rich in $\mathrm{S}$, and cysteine and methionine, compared with casein, which contains methionine but only a negligible amount of cysteine (Fox et al., 2015).

\section{CONCLUSIONS}

The current study added new knowledge on the mineral profile of donkey milk, which is relevant for the characterization of the nutritional and technological properties of such a milk. The fat fraction carries no or very little amount of the investigated elements. The casein fraction carries the majority of milk Ca and P. Whey proteins carry a small, although significant, amount of $\mathrm{Ca}, \mathrm{P}, \mathrm{Mg}$, and $\mathrm{K}$. The aqueous phase of milk contains all $\mathrm{Na}$ and almost all K. Current results confirm that donkey casein binds a larger amount of $\mathrm{Ca}$ and P per unit of weight, likely as CCP, compared with published data on cow milk, and this is likely related to the higher $\mathrm{pH}$ of donkey milk. Furthermore, the majority of milk $\mathrm{S}$ is associated with whey proteins and only one-fourth of this element is associated with casein, indicating a higher content of S-containing amino acids in donkey whey proteins than in casein. Based on the results presented here, further research could clarify factors affecting the distribution of minerals and caseins in donkey milk to optimize methods for donkey milk processing throughout the dairy chain, including yogurt and cheese-making. Finally, current results can represent a basis for the assessing of mineral digestibility of donkey milk.

\section{ACKNOWLEDGMENTS}

Funds by F. Fantuz, S. Ferraro, and L. Todini (Università di Camerino, Camerino, Italy), and by E. Salimei (Università del Molise, Campobasso, Italy) were used for this study. The authors gratefully acknowledge the valuable collaboration of C. Merlo and his donkeys 
(Azienda Agricola Ciucolandia, Capestrano, L'Aquila, Italy). The authors have not stated any conflicts of interest.

\section{REFERENCES}

Ahmad, S., M. Piot, F. Rousseau, J. F. Grongnet, and F. Gaucheron. 2009. Physico-chemical changes in casein micelles of buffalo and cow milks as a function of alkalinisation. Dairy Sci. Technol. 89:387-403. https://doi.org/10.1051/dst/2009020.

Anastácio, A., C. L. da Silveira, N. Miekeley, and C. M. Donangelo. 2004. Distribution of lead in human milk fractions: Relationship with essential minerals and maternal blood lead. Biol. Trace Elem. Res. 102:27-37. https://doi.org/10.1385/BTER:102:1-3:027.

Aoki, T., N. Yamada, and Y. Kako. 1990. Relation between colloidal calcium phosphate cross-linkage and release of $\beta$-casein from bovine casein micelles on cooling. Agric. Biol. Chem. 54:2287-2292.

AOAC International. 2000. Official Methods of Analysis. 17th ed. AOAC International, Gaithersburg, MD.

Bijl, E., H. J. F. van Valenberg, T. Huppertz, and A. C. M. van Hooijdonk. 2013. Protein, casein, and micellar salts in milk: Current content and historical perspectives. J. Dairy Sci. 96:5455-5464. https://doi.org/10.3168/jds.2012-6497.

Bilandzic, N., M. Sedak, M. Dokic, B. Solomun Kolanovic, I. Varenina, D. Bozic, and A. Koncurat. 2014. Differences of the essential mineral element levels in the milk of Croatian Coldblood horse and Littoral-Dinaric donkey. Mljekarstvo 64:12-18.

Cava-Montesinos, P., M. L. Cervera, A. Pastor, and M. de la Guardia. 2005. Room temperature acid sonication ICP-MS multielemental analysis of milk. Anal. Chim. Acta 531:111-123. https://doi.org/ 10.1016/j.aca.2004.09.093.

Cunsolo, V., R. Saletti, V. Muccilli, S. Gallina, A. Di Francesco, and S. Foti. 2017. Proteins and bioactive peptides from donkey milk: The molecular basis for its reduced allergenic properties. Food Res. Int. 99:41-57. https://doi.org/10.1016/j.foodres.2017.07.002.

Dalgleish, D. G. 2011. On the structural models of bovine casein micelles - Review and possible improvements. Soft Matter 7:22652272. https://doi.org/10.1039/C0SM00806K.

Dalgleish, D. G., and M. Corredig. 2012. The structure of the casein micelle of milk and its changes during processing. Annu. Rev. Food Sci. Technol. 3:449-467. https://doi.org/10.1146/annurev-food -022811-101214.

Darragh, A., and B. Lonnerdal. 2011. Human milk. Pages 581-590 in Encyclopedia of Dairy Sciences. Vol. 3. 2nd ed. J. W. Fuquay, P. F. Fox, and P. L. H. McSweeney, ed. Academic Press, San Diego, CA.

European Union. 2010. Directive 2010/63/EU of the European Parliament and of the Council of 22 September 2010 on the protection of animals used for scientific purposes. Off. J. European Union. L 276:33-79

Faccia, M., G. Gambacorta, G. Martemucci, G. Natrella, and A. G. D'Alessandro. 2018. Technological attempts at producing cheese from donkey milk. J. Dairy Res. 85:327-330. https://doi.org/10 $.1017 /$ S0022029918000420.

Fantuz, F., S. Ferraro, L. Todini, R. Piloni, P. Mariani, and E. Salimei. 2012. Donkey milk concentration of calcium, phosphorus, potassium, sodium and magnesium. Int. Dairy J. 24:143-145. https:// doi.org/10.1016/j.idairyj.2011.10.013.

Fantuz, F., C. Maglieri, G. Lebboroni, and E. Salimei. 2009. Ca, Mg, $\mathrm{Zn}, \mathrm{Fe}, \mathrm{Cu}$ and $\mathrm{Mn}$ content of ass's milk. Ital. J. Anim. Sci. 8(Suppl. 2):703-705. https://doi.org/10.4081/ijas.2009.s2.703.

Fantuz, F., E. Salimei, and P. Papademas. 2016. Macro- and micronutrients in non-cow milk and products and their impact on human health. Pages 209-261 in Non-Bovine Milk and Milk Products. E. Tsakalidou and K. Papadimitriou, ed. Academic Press, London, UK.

Fox, P. F., T. Uniacke-Lowe, P. L. H. McSweeney, and J. A. O'Mahony. 2015. Dairy chemistry and biochemistry, 2nd ed. Springer International Publishing Switzerland. Cham, Switzerland.
Gaucheron, F. 2011. Milk salts: Distribution and analysis. Pages 908 916 in Encyclopedia of Dairy Sciences. Vol. III. 2nd ed. J. W. Fuquay, P. F. Fox, and P. L. H. McSweeney, ed. Academic Press, San Diego, CA.

Giufrida, M. G., A. Cantisani, L. Napolitano, A. Conti, and J. Godovac-Zimmermann. 1992. The amino-acid sequence of two isoforms of a-Lactalbumin from donkey (Equus asinus) milk is identical. Biol. Chem. Hoppe Seyler 373:931-936. https://doi.org/10.1515/ bchm3.1992.373.2.931.

Godovac-Zimmermann, J., A. Conti, and L. Napolitano. 1988. The primary structure of donkey (Equus asinus) lysozyme contains the $\mathrm{Ca}$ (II) binding site of $\alpha$-lactalbumin. Biol. Chem. Hoppe Seyler 369:1109-1116. https://doi.org/10.1515/bchm3.1988.369.2.1109.

Guo, H. Y., K. Pang, X. Y. Zhang, L. Zhao, S. W. Chen, M. L. Dong, and F. Z. Ren. 2007. Composition, physicochemical properties, nitrogen fraction distribution, and amino acid profile of donkey milk. J. Dairy Sci. 90:1635-1643. https://doi.org/10.3168/jds.2006-600.

Holt, C., J. A. Carver, H. Ecroyd, and D. C. Thorn. 2013. Casein and the casein micelle: Their biological functions, structures, and behavior in foods. J. Dairy Sci. 96:6127-6146.

Holt, C., and R. Jennes. 1984. Interrelationships of constituents and partition of salts in milk samples from eight species. Comp. Biochem. Physiol. 77A:275-282.

Horne, D. S. 1998. Casein interactions: Casting light on the black boxes, the structure in dairy products. Int. Dairy J. 8:171-177. https://doi.org/10.1016/S0958-6946(98)00040-5.

Li, C. P., J. L. Peng, G. H. Zhu, H. Zhao, and C. Li. 2010. Micellar calcium phosphate-cross-linkage in donkey casein micelles. Milchwissenschaft 65:274-276.

Lonnerdal, B. 1997. Effects of milk and milk components on calcium, magnesium, and trace element absorption during infancy. Physiol. Rev. 77:643-669. https://doi.org/10.1152/physrev.1997.77.3.643.

Malacarne, M., A. Criscione, P. Franceschi, S. Bordonaro, P. Formaggioni, D. Marletta, and A. Summer. 2019. New insights into chemical and mineral composition of donkey milk throughout nine months of lactation. Animals (Basel) 9:1161. https://doi.org/10 .3390/ani9121161.

Malacarne, M., A. Criscione, P. Franceschi, S. Tumino, S. Bordonaro, F. Di Frangia, D. Marletta, and A. Summer. 2017. Distribution of $\mathrm{Ca}, \mathrm{P}$ and $\mathrm{Mg}$ and casein micelle mineralisation in donkey milk from the second to ninth month of lactation. Int. Dairy J. 66:1-5. https://doi.org/10.1016/j.idairyj.2016.11.002.

Malacarne, M., P. Franceschi, P. Formaggioni, G. M. Pisani, F. Petrera, F. Abeni, C. S. Soffiantini, and A. Summer. 2015. Minerals content and distribution in milk from red deer (Cervus elaphus), fallow deer (Dama dama) and roe deer (Capreolus capreolus). Small Rumin. Res. 130:208-215. https://doi.org/10.1016/j.smallrumres 2015.07.005.

Martini, M., I. Altomonte, R. Licitra, and F. Salari. 2018. Short communication: Technological and seasonal variations of vitamin $\mathrm{D}$ and other nutritional components in donkey milk. J. Dairy Sci. 101:8721-8725. https://doi.org/10.3168/jds.2018-14776.

Massouras, T., K. A. Triantaphyllopoulos, and I. Theodossiou. 2017. Chemical composition, protein fraction and fatty acid profile of donkey milk during lactation. Int. Dairy J. 75:83-90. https://doi .org/10.1016/j.idairyj.2017.06.007.

McDowell, L. R., and G. Valle. 2000. Major minerals in forages. Pages 373-397 in Forage Evaluation in Ruminant Nutrition. D. I. Givens, E. Owen, R. F. E. Axford, and H. M. Omed, ed. CABI Publishing, Wallingford, UK.

McGann, T. C. A., and G. T. Pyne. 1960. The colloidal phosphate of milk. III. Nature of its association with casein. J. Dairy Res. 27:403-417. https://doi.org/10.1017/S0022029900010487.

Miraglia, N., E. Salimei, and F. Fantuz. 2020. Equine milk production and valorization of marginal areas-A review. Animals (Basel) 10:353. https://doi.org/10.3390/ani10020353.

Nakai, S., and E. Li-Chan. 1987. Effect of clotting in stomachs of infants on protein digestibility of milk. Food Structure 6:161-170.

Niro, S., A. Fratianni, G. Colavita, L. Galassi, M. Zanazzi, and E. Salimei. 2017. Technological use of donkey milk in cheesemaking. 
Int. J. Dairy Technol. 70:439-442. https://doi.org/10.1111/1471 -0307.12342 .

O'Connor, P., and P. Fox. 1973. Temperature dependent dissociation of casein micelles from milk of various species. Neth. Milk Dairy J. 27:199-217.

O'Connor, P., and P. Fox. 1977. The proteins and salts of some nonbovine milks. J. Dairy Res. 44:607-609. https://doi.org/10.1017/ S0022029900020574.

Ochirkhuyag, B., J. M. Chobert, M. Dalgalarrondo, and T. Haertlé 2000. Characterization of mare caseins. Identification of $\alpha_{\mathrm{S}^{-}}$and $\alpha_{S_{2}}$-caseins. Lait 80:223-235. https://doi.org/10.1051/lait:2000121.

Ozcan, T., D. Horne, and J. A. Lucey. 2011. Effect of increasing the colloidal calcium phosphate of milk on the texture and microstructure of yogurt. J. Dairy Sci. 94:5278-5288. https://doi.org/ $10.3168 /$ jds.2010-3932.

Salimei, E. 2011. Animals that produce dairy foods - Donkey. Pages 365-373 in Encyclopedia of Dairy Sciences. Vol. I. 2nd ed. J. W. Fuquay, P. F. Fox and P. L. H. McSweeney, ed. Academic Press, San Diego, CA.

Salimei, E., and F. Fantuz. 2013. Horse and donkey milk. Pages 594613 in Milk and Dairy Product in Human Nutrition: Production, Composition and Health. Y. W. Park and G. F. W. Haenlein, ed. John Wiley \& Sons, Oxford, UK.

Salimei, E., F. Fantuz, R. Coppola, B. Chiofalo, P. Polidori, and G. Varisco. 2004. Composition and characteristics of ass's milk. Anim. Res. 53:67-78. https://doi.org/10.1051/animres:2003049.

Šarić, L. C., B. M. Saric, A. I. Mandic, Z. S. Kevresan, B. B. Ikonic, S. Z. Kravic, and D. J. Jambrec. 2014. Role of calcium content in antibacterial activity of donkeys' milk toward E. coli. Eur. Food Res. Technol. 239:1031-1039. https://doi.org/10.1007/s00217-014 $-2299-4$

Sarti, L., M. Martini, G. Brajon, S. Barni, F. Salari, I. Altomonte, G. Ragona, F. Mori, N. Pucci, G. Muscas, F. Belli, F. Corrias, and E. Novembre. 2019. Donkey's milk in the management of children with cow's milk protein allergy: Nutritional and hygienic aspects.
Ital. J. Pediatr. 45:102-110. https://doi.org/10.1186/s13052-019 $-0700-4$.

Stergiadis, S., N. P. Nørskov, S. Purup, I. Givens, and M. R. F. Lee. 2019. Comparative nutrient profiling of retail goat and cow milk. Nutrients 11:2282. https://doi.org/10.3390/nu11102282.

Suttle, N. F. 2010. The Mineral Nutrition of Livestock. 4th ed. CAB International, Wallingford, UK.

Turchi, B., F. Pedonese, B. Torracca, F. Fratini, S. Mancini, A. Galiero, B. Montalbano, D. Cerri, and R. Nuvoloni. 2017. Lactobacillus plantarum and Streptococcus thermophilus as starter cultures for a donkey milk fermented beverage. Int. J. Food Microbiol. 256:54-61. https://doi.org/10.1016/j.ijfoodmicro.2017.05.022.

Uniacke-Lowe, T. 2011. Studies on equine milk and comparative studies on equine and bovine milk systems. PhD Thesis, School of Food and Nutritional Sciences, University College Cork, Ireland.

Uniacke-Lowe, T., F. Chevalier, S. Hem, P. F. Fox, and D. M. Mulvihill. 2013. Proteomic comparison of equine and bovine milks on renneting. J. Agric. Food Chem. 61:2839-2850. https://doi.org/10 $.1021 / \mathrm{jf3045846.}$

Vaia, B. M. A. Smiddy, A. L. Kelly, and T. Huppertz. 2006. Solventmediated disruption of bovine casein micelles at alkaline $\mathrm{pH}$. J. Agric. Food Chem. 54:8288-8293. https://doi.org/10.1021/jf061417c.

\section{ORCIDS}

F. Fantuz @ https://orcid.org/0000-0002-6464-4636

S. Ferraro 10 https://orcid.org/0000-0001-7193-0668

L. Todini $\odot$ https://orcid.org/0000-0003-2820-6388

L. Cimarelli (i) https://orcid.org/0000-0002-2026-1940

A. Fatica (®) https://orcid.org/0000-0003-0207-089X

F. Marcantoni (i) https://orcid.org/0000-0002-7779-203X

E. Salimei ๑ https://orcid.org/0000-0001-9945-1458 